\title{
The 100 Top-cited Studies on Ebola: A Bibliometric Analysis
}

\author{
Joseph Kawuki ${ }^{1,2 \star}$, Taha Hussein Musa ${ }^{3,4}$, Shireen Salome Papabathini ${ }^{2}$, Upama Ghimire ${ }^{2}$, Nathan Obore ${ }^{2}$, \\ Xiaojin $\mathrm{Yu}{ }^{2,3}$
}

\begin{abstract}
${ }^{1}$ Centre for Health Behaviours Research, Jockey Club School of Public Health and Primary Care, Faculty of Medicine, The Chinese University of Hong Kong, CHINA ${ }^{2}$ Key Laboratory of Environmental Medicine Engineering, Ministry of Education, Department of Global Health, School of Public Health, Southeast University, Nanjing, 210009, Jiangsu Province, CHINA

${ }^{3}$ Key Laboratory of Environmental Medicine Engineering, Department of Epidemiology and Health Statistics, School of Public Health, Southeast University, Nanjing, 210009, Jiangsu Province, CHINA

${ }^{4}$ Biomedical Research Institute, Darfur College, Nyala, SUDAN

*Corresponding Author: Joseks256@gmail.com
\end{abstract}

Citation: Kawuki J, Musa TH, Papabathini SS, Ghimire U, Obore N, Yu X. The 100 Top-cited Studies on Ebola: A Bibliometric Analysis. Electron J Gen Med. 2021;18(2):em276. https://doi.org/10.29333/ejgm/9694

ARTICLE INFO

Received: 24 Aug. 2020

Accepted: 1 Dec. 2020

\begin{abstract}
The achievements in Ebola virus disease (EVD) prevention and control can be reflected by scientific studies, particularly in the top-cited studies. The study thus aimed to identify and characterise the 100 top-cited studies of EVD. The study used a retrospective bibliometric-analysis, which was performed in January 2020. Studies were searched from the Web of Science using keywords: "Ebola" or "Ebola virus" or "Ebola virus disease" to identify the 100 top-cited EVD studies. Studies were analysed for the number of citations, authorship, and journal, year of publication, country and institution. The analyses were carried out using SPSS, HistCite and VOSviewer. The 100 top-cited studies were published between 1977 and 2017, cited from 169 to 808 times and had an average citation of 290.5 , and 8 studies were cited more than 500 times. They were published in 31 journals, and the Journal of Virology published most of the studies $(n=14)$. They were produced by 33 countries, and the USA published most of the studies (63), followed by Germany (8) and Gabon (6). CDC-USA (26) was the leading institution, while Geisbert TW and Sanchez A were the most productive authors. This study provides insights into the historical advancements reflected by the top-cited studies and has highlighted the leading roles played by various stakeholders in addressing EVD. However, the contribution of African countries is not sufficiently reflected among these studies, and so more focus, funding and involvement in clinical research is needed for effective prevention and control of EVD in Africa.
\end{abstract}

Keywords: Ebola, bibliometric analysis, 100 top-cited, citation classics, Web of Science

\section{INTRODUCTION}

Ebola virus disease (EVD) is a severe, often fatal zoonosis that is highly infectious in humans [1]. It is caused by negativestranded RNA viruses, belonging to the Filoviridae family, which are endemic to regions of the west and equatorial Africa [2]. The first EVD human case was identified in 1976 in Zaire, the now called the Democratic Republic of Congo (DRC) [3]. Since then, there have been over 30 documented outbreaks with the worst, and most publicised being the 2014 West African outbreak and the recent 2018-2020 Kivu outbreak in DRC $[3,4]$.

The origin of the Ebola Virus is not known, but in most outbreaks, it is suspected to be introduced into the human population via forest bats and other wild animals [5]. EVD is known to present with flu-like symptoms, persistent fever, and severe complications such as respiratory disorders, symptoms of hemorrhagic diathesis, among others [6]. In the previous EVD outbreaks, the case fatality of around $25-90 \%$ has been reported [1,2]. The severity of the epidemic has been attributed with the species involved, and the Zaire ebolavirus species is the most lethal strain of the six known Ebola virus sub-strains [3].
Despite the recurrent outbreaks and other challenges, several studies on Ebola have been conducted over time, with remarkable progress in vaccine development [7], as well as prevention and control of EVD [8,9]. The achievements in EVD prevention and control can be reflected by scientific studies, particularly in the top-cited studies [10,11]. Citation analysis, a type of bibliometric analysis involves the evaluation and ranking of an article based on citation count [12]. Identification of milestones in a particular field can be done by analysing the most cited studies, especially the 100 top-cited studies [13-15]. Evaluation of the 100 top-cited studies had been conducted for various medical fields and diseases, including Gastritis [15], Depression [14], Vaccines [16], Arthritis [17], among others. However, there is no such study conducted on Ebola. Thus, we performed this study to identify and characterise the 100 topcited studies of Ebola virus disease.

\section{METHODS}

The study was a retrospective bibliometric analysis, and no ethical approval was required since the data used was from a 


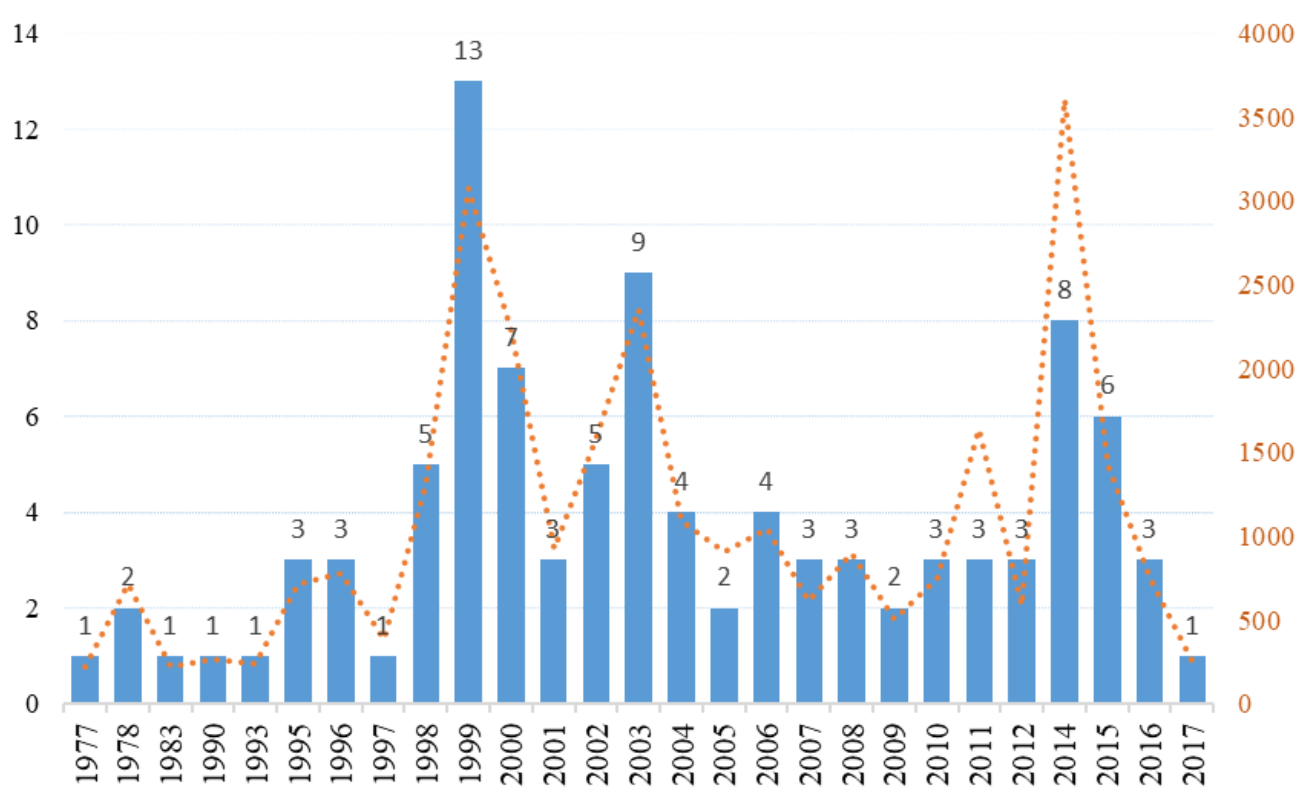

Number of studies Total citations

Figure 1. Annual trend and citation of EVD publications (1977 to 2017)

public database, and no human or animal subject was directly involved.

\section{Search Method and Strategy}

We performed a search on $13^{\text {th }}$ January 2020 using the Web of Science Core Collection database hosted by Clarivate Analytics as the previous studies [14,17]. The Web of Knowledge Core Collection is a multidisciplinary database with searchable author abstracts and fully indexes the major journals, more than 170 subject categories, and thus provides access to current information and retrospective data from 1900 forward. The following keywords were used for searching the relevant studies: "Ebola" or "Ebola virus" or "Ebola virus disease" in the titles or abstracts of the papers. However, based on a pilot search, the authors found that some top-cited articles mentioning the word Ebola in the abstract are not related to the Ebola, and these studies were excluded. The search was also refined to only research articles for a precise evaluation of the top-cited EVD studies; other document types were excluded from the analysis. The identified publications were sorted in descending order of citation times and then downloaded as full records in plain text format for further analysis.

\section{Data Extraction}

The following data were extracted, including the author, affiliation, country, journal, language, document type, research field, publication year, and the number of citations. The journal impact factor was obtained from Journal Citation Reports (JCR) CRanking: 2019 [18].

\section{Bibliometric and Statistical Analysis}

The bibliometric indicators of Ebola studies such as trends of publication, distribution of countries, journals, authors, and institutions, total citations, average citations per item, and hindex, were evaluated using HistCite Software [19], and "Bibliometrix app."- (using R-studio cloud) [20]. Microsoft Excel and VOSviewer (Van Eck \& Waltman, Leiden University,
The Netherlands) were used for data mining, mapping and visualisation of the bibliometric networks [21].

Statistical analyses were executed using Statistical Package for the Social Sciences for windows software (version 20.0, IBM SPSS-Chicago, IL: SPSS Inc.). Frequency statistics of the 100 top-cited articles were reported. A nonparametric Spearman correlation $(r)$ was used to identify the association between the number of citations and various study variables. A $\mathrm{P}$-value of $<.05$ was considered statistically significant.

\section{RESULTS}

\section{Citation Classics of the 100 Top-cited Studies}

The 100 top-cited articles are listed in Appendix 1. The number of citations ranged from 169 to 808 , with a total number of citations equal to 29,026 and average citations of 290.5 per document. Eight studies were cited more than 500 times, and no single-authored paper was noted. The most cited study was published by Aylward B et al., 2014 in the New England Journal of Medicine, with 808 citations.

\section{Production Trend of the Top-cited Studies}

All the 100 top-cited studies were published in the English language. They were published during a span of 40 years from 1977 to 2017; most of the studies were done and published in the late 1990s and 2000s. We found that the highest number of studies was published in 1999 ( $n=13$ ), 2003 (9) and 2014 (8). The annual total citation followed an almost similar trend, with 2014 receiving the highest citations of over 3600 (Figure 1).

\section{Most Productive Journals}

The 100 top-cited articles were published in 31 journals, of which 10 journals published more than 1 study. The most productive journals were United States (US) and United Kingdom (UK) journals, which included the Journal of Virology ( $n=14$, total citation $(T C)=3620$ ), followed by Journal of Infectious Diseases (9) and Lancet (9), among others. Overall, 
Table 1. Journals that published three or more of the 100 top-cited studies

\begin{tabular}{|c|c|c|c|c|c|c|}
\hline Rank & Journal & Country location & Number of studies & IF (2019) & $h$-index & Total citations \\
\hline 1 & Journal of Virology & United States & 14 & 4.16 & 14 & 3620 \\
\hline 2 & Journal of Infectious Diseases & United States & 9 & 4.73 & 9 & 2001 \\
\hline 3 & Lancet & United Kingdom & 9 & 43.38 & 9 & 2857 \\
\hline 4 & New England Journal of Medicine & United States & 9 & 37.91 & 9 & 3094 \\
\hline 5 & $\begin{array}{l}\text { Proceedings of the National Academy of } \\
\text { Sciences of USA }\end{array}$ & Unites States & 9 & 9.35 & 9 & 2605 \\
\hline 6 & Science & United States & 8 & 41.84 & 8 & 2602 \\
\hline 7 & Nature & United Kingdom & 7 & 24.36 & 7 & 3117 \\
\hline 8 & Nature Medicine & United States & 5 & 22.66 & 5 & 1756 \\
\hline 9 & PLoS Pathogens & United States & 4 & 6.18 & 4 & 965 \\
\hline 10 & Bulletin of the World Health Organization & Switzerland & 3 & 5.94 & 3 & 935 \\
\hline
\end{tabular}

Table 2. Countries that lead one or more of the 100 top-cited studies of EVD

\begin{tabular}{|c|c|c|c|c|c|}
\hline Rank & Country & Number of studies & Single-country Studies & Multiple Country Studies & Total citations \\
\hline 1 & USA & 63 & 32 & 31 & 17405 \\
\hline 2 & Germany & 8 & 4 & 4 & 2522 \\
\hline 3 & Gabon & 6 & 0 & 6 & 1663 \\
\hline 4 & Canada & 4 & 1 & 3 & 1006 \\
\hline 5 & France & 3 & 0 & 3 & 621 \\
\hline 6 & United Kingdom & 3 & 1 & 2 & 1409 \\
\hline 7 & Netherlands & 2 & 2 & 0 & 826 \\
\hline 8 & Switzerland & 2 & 0 & 2 & 671 \\
\hline 9 & Belgium & 1 & 0 & 1 & 242 \\
\hline 10 & Congo & 1 & 1 & 0 & 443 \\
\hline 11 & Japan & 1 & 0 & 1 & 227 \\
\hline 12 & Russia & 1 & 1 & 0 & 268 \\
\hline 13 & Sierra Leone & 1 & 0 & 1 & 610 \\
\hline 14 & South Africa & 1 & 1 & 0 & 211 \\
\hline 15 & Spain & 1 & 1 & 0 & 417 \\
\hline
\end{tabular}

Table 3. Authors that contributed to at least seven of the 100 top-cited EVD studies

\begin{tabular}{|c|c|c|c|c|c|c|c|}
\hline Rank & Author & Author's Affiliation & $\begin{array}{c}\text { Number of } \\
\text { studies }\end{array}$ & $\begin{array}{c}\text { 1st } \\
\text { author }\end{array}$ & $\begin{array}{c}\text { 2nd } \\
\text { author }\end{array}$ & $\begin{array}{c}\text { 3rd or Last } \\
\text { author }\end{array}$ & $\begin{array}{c}\text { Total } \\
\text { citations }\end{array}$ \\
\hline 1 & Geisbert Thomas W & US Army of Medical Research Institute of Infectious Diseases & 13 & 5 & 4 & 4 & 3923 \\
\hline 2 & Sanchez Anthony & Centers for Disease Control and Prevention USA & 13 & 3 & 2 & 8 & 3561 \\
\hline 3 & Rollin Pierre E & Centers for Disease Control and Prevention USA & 12 & 0 & 3 & 9 & 3310 \\
\hline 4 & Jahrling Peter B & US Army of Medical Research Institute of Infectious Diseases & 11 & 2 & 0 & 9 & 2796 \\
\hline 5 & Peters Clarence J & US Army of Medical Research Institute of Infectious Diseases & 11 & 0 & 0 & 11 & 2622 \\
\hline 6 & Nichol Stuart T & Centers for Disease Control and Prevention USA & 10 & 0 & 0 & 10 & 2558 \\
\hline 7 & Gunther Stephan & Bernhard Nocht Institute of Tropical Medicine Germany & 8 & 0 & 0 & 8 & 2731 \\
\hline 8 & Hensley Lisa E & US Army of Medical Research Institute of Infectious Diseases & 8 & 0 & 3 & 5 & 2130 \\
\hline 9 & Ksiazek Thomas G & Centers for Disease Control and Prevention USA & 8 & 1 & 0 & 7 & 2026 \\
\hline 10 & Geisbert Joan B & US Army of Medical Research Institute of Infectious Diseases & 7 & 0 & 0 & 7 & 2028 \\
\hline 11 & Klenk Hans-Dieter & Philipps University of Marburg Germany & 7 & 0 & 0 & 7 & 2138 \\
\hline 12 & Volchkov Viktor E & Philipps University of Marburg Germany & 7 & 3 & 0 & 4 & 2022 \\
\hline
\end{tabular}

the 10 top journals published over three thirds (77\%) of the topcited EVD studies. The impact factors (IF) of the top journals ranged from 4.16 to 43.38 , while their $h$-index ranged from 2 to 14 (Table 1).

\section{Country Contribution and Most Cited Countries}

The top cited studies were produced by 33 countries, of which 15 countries were corresponding author countries that chaired one or more of the 100 top-cited EVD studies. The USA chaired 63 studies, followed by Germany (8) and Gabon (6). Regarding single-country studies (SCS), still, the USA and Germany topped the list with 32 and 4 studies respectively. Only two SCS came from Africa being produced from DRC and South Africa, as shown in Table 2. The most cited countries included USA (TC=17405), Germany (2522), Gabon (1663), United Kingdom (1409), among others.

\section{Most Contributing Authors}

The 100 studies were written by 1028 authors, and 12 authors wrote at least 7 articles. All the 100 studies were done in collaboration amongst different authors, no single-authored study was recorded, and authors per document was 10.3 with a Collaboration index of 10.3. The most productive authors of these studies included Geisbert TW and Sanchez A, both with 13 papers, followed by Rollin PE (12), Jahrling PB (11) and Peters CJ (11), among others. The top productive authors were mainly from the US and Germany institutions such as US Army of Medical Research Institute of Infectious Diseases (USAMRIID), CDC-USA, among others (Table 3).

\section{Most Productive Organisations}

The 100 studies were from 271 institutions, and 14 contributed to five or more studies. The leading productive 
Table 4. Institutions that produced five or more of the top-cited EVD studies

\begin{tabular}{|c|c|c|c|}
\hline Rank & Institution & Region/Country location & Number of studies \\
\hline 1 & Centers for Disease Control and Prevention USA & United States & 26 \\
\hline 2 & US Army of Medical Research Institute of Infectious Diseases & United States & 21 \\
\hline 3 & Institute Pasteur & France & 10 \\
\hline 4 & World Health Organisation & Switzerland & 10 \\
\hline 5 & Harvard University & United States & 9 \\
\hline 6 & University of Marburg & Germany & 9 \\
\hline 7 & University of Pennsylvania & United States & 8 \\
\hline 8 & Ministries of Health & African countries & 7 \\
\hline 9 & Bernhard Nocht Institute for Tropical Medicine & Germany & 6 \\
\hline 10 & NIH National Institute of Allergy Infectious Diseases & United States & 6 \\
\hline 11 & Franceville International Centre for Medical Research & Gabon & 5 \\
\hline 12 & Public Health Agency of Canada & Canada & 5 \\
\hline 13 & Public Health of England & United Kingdom & 5 \\
\hline 14 & University of Manitoba & Canada & 5 \\
\hline
\end{tabular}

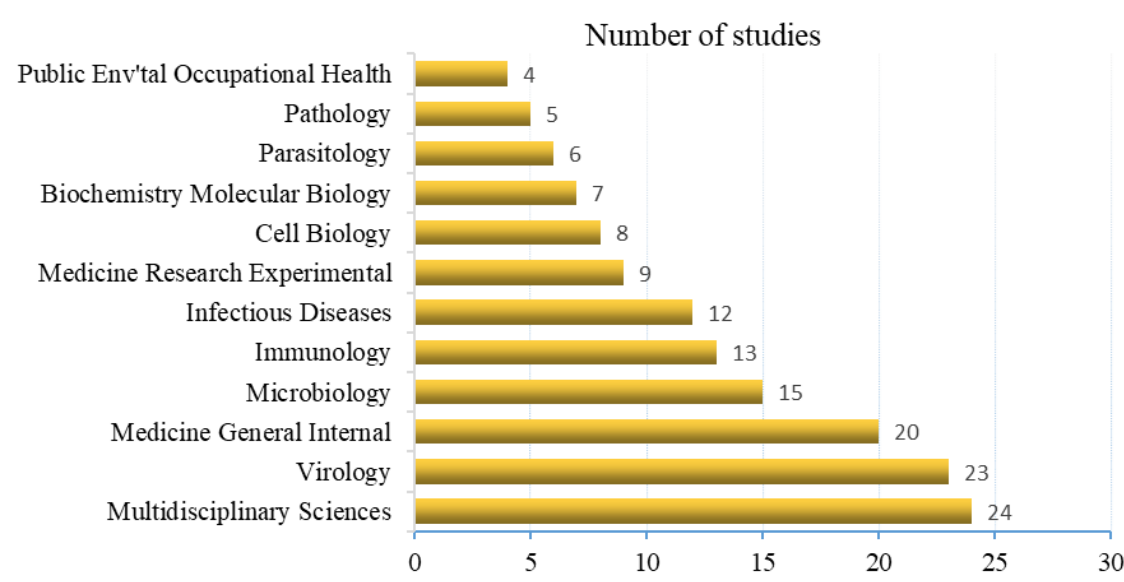

(a)

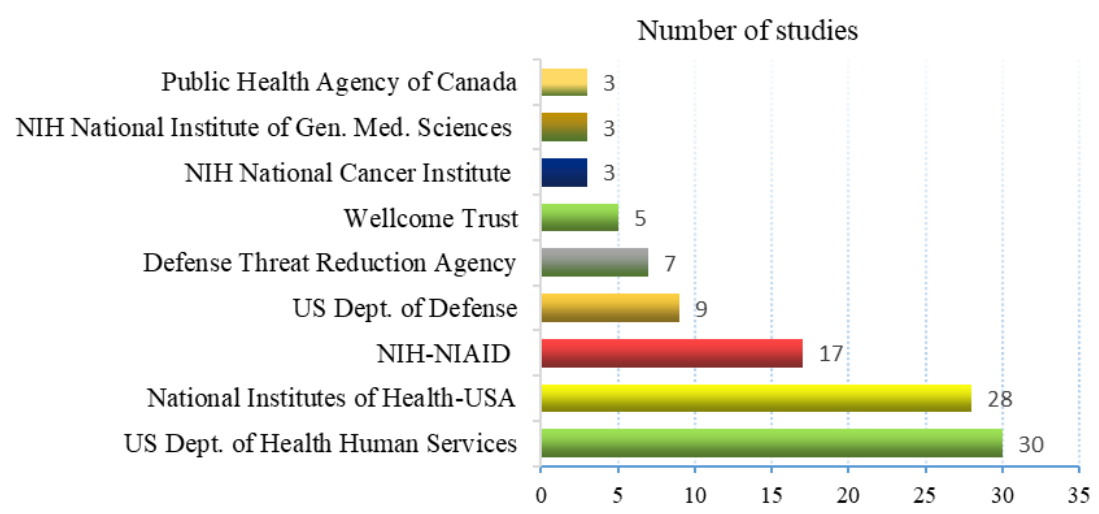

(b)

Figure 2. Most crucial Research fields and Funding institutions. (a) Research fields with at least four studies. (b) Institutions that financed three or more EVD studies.

institutions included Centre of Disease Control \& Prevention USA (26), US Army of Medical Research Institute of Infectious Diseases (21), Institute Pasteur (10) and World Health Organisation (10), among others. Among African institutions, the International Centre for Medical Research in Franceville Gabon (5) led the list. In addition, Ministries of Health of several EVD endemic African countries also collectively contributed to seven studies, as show in Table 4.

\section{Most Crucial Research Fields and Funding Institutions}

The top cited studies belonged to 17 research fields according to the Web of Science categories, and 12 fields had 4 or more studies. The most popular research field was "Multidisciplinary Sciences" with 24 studies, followed by "Virology" and "Medicine General Internal" with 23 and 20 studies respectively (Figure $\mathbf{2 a}$ ).

The studies were funded by 55 organisations, and 9 institutions financed 3 or more studies. Most of these were USA institutions and included the United States Department of Health Human Services $(n=30)$, National Institutes of Health NIH USA (28), National Institute of Allergy Infectious Diseases NIAID (17), amongst others (Figure 2b). 


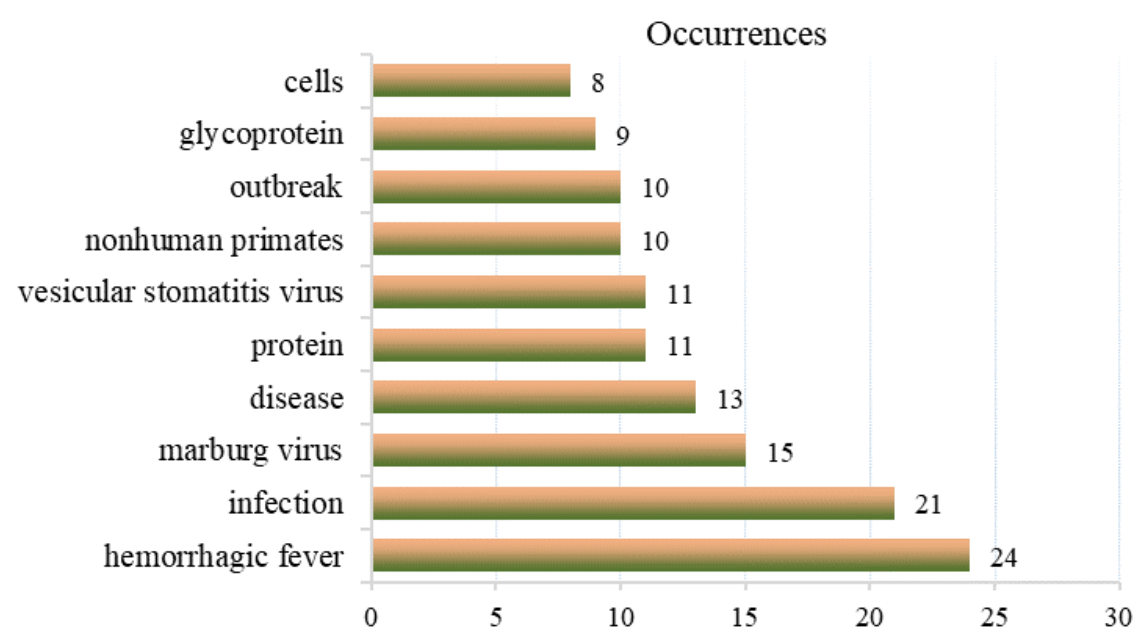

(a)

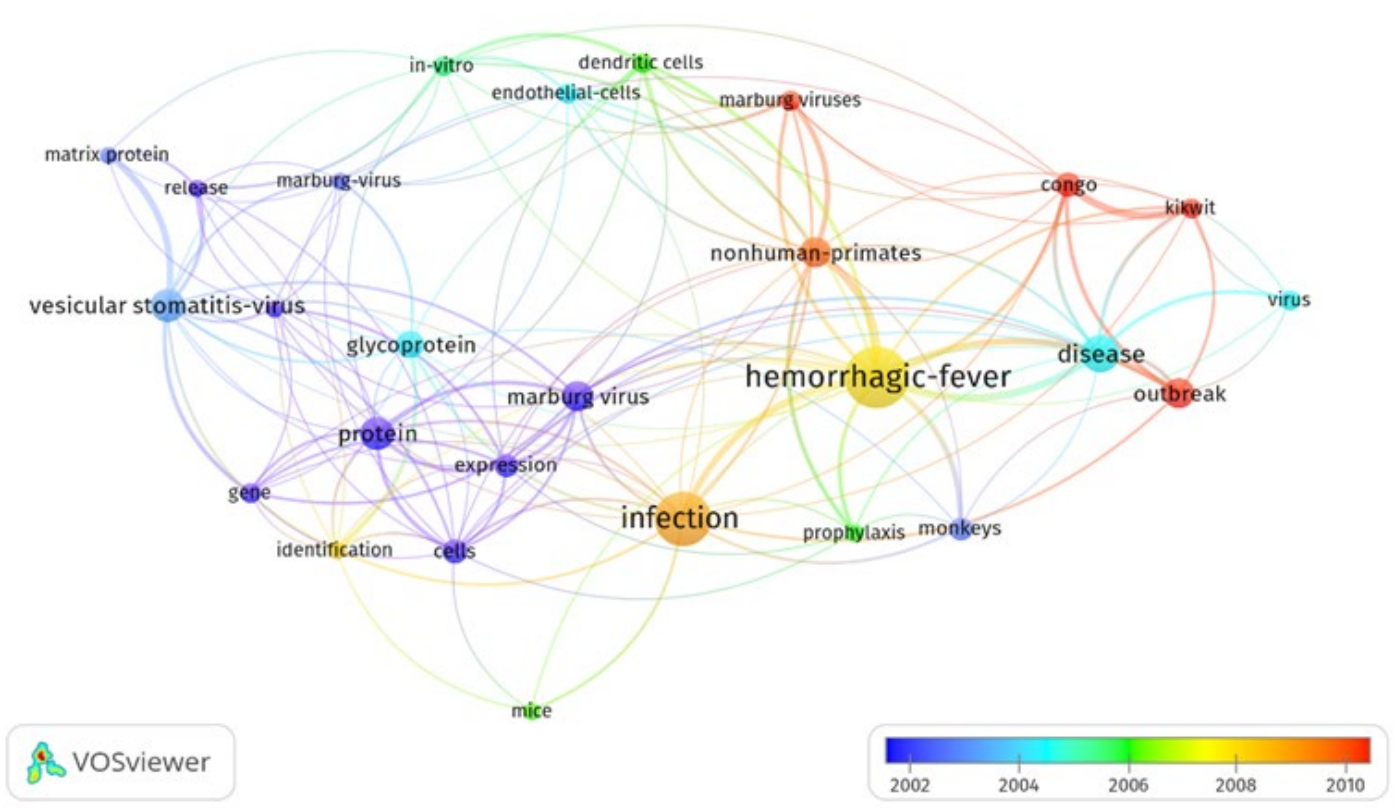

(b)

Figure 3. Analysis of Keywords. (a) Keywords plus with eight or more occurrence. (b) Overlay visualisation of keywords plus based on occurrence

\section{Analysis of Keywords}

The studies all together had 48 author keywords and 368 keywords plus. Ten keywords plus appeared more than 8 times, as shown in Figure 3a. Co-occurrence analysis showed "hemorrhagic fever" as the most co-occurred keyword plus with 24 occurrences, 21 links and 54 total link strength. This was followed by "infection", "Marburg virus" and "disease", among others (Figure 3b). Note that a minimum of 5 occurrences was set and 27 keywords plus met the threshold.

\section{Possible Factors Influencing the Number of Citations}

The correlation was also calculated to evaluate the potential relationships between the number of citations and the number of authors, journals' productivity, and years since publication, and countries involved. Significant correlations were noted between the number of citations and the journal's $h$-index $(r=0.86, P<0.0004)$, the impact factor $(r=0.59, P=0.0446)$,
Table 5. Factors affecting the number of citations

\begin{tabular}{ccc}
\hline Factor & Spearman's r & P value \\
\hline Journal $h$ - index & 0.86 & 0.0004 \\
\hline Journal impact factor & 0.59 & 0.0446 \\
\hline Years since publication & 0.31 & 0.1139 \\
\hline Number of countries & 0.86 & $<0.0001$ \\
\hline Number of authors & 0.03 & 0.7657 \\
\hline
\end{tabular}

and the number of countries per study $(0.86, \mathrm{P}=<0.0001)$ (Table 5).

\section{DISCUSSION}

The present study is the first bibliometric study summarising several features of the most influential studies on EVD. Understanding the characteristics of these studies may be 
valuable since these studies cover essential advancements in the EVD research field.

In this analysis, the 100 top-cited studies were conducted between 1977 and 2017, with citations ranging from 169 to 808 . Compared to other health fields like cancer [22] and vaccines [17], the citations of EVD studies are less, possibly due to less novelty of this topic in the developed countries. The year of 1999 witnessed the most significant advancements in EVD research with 13 most cited studies. Most of these studies focused on identification and characterisation of the Ebola viruses [23,24], as well as treatment [25,26], prevention and control of Ebola outbreaks [27,28]. Although several recognisable studies have been done since the late 1970s, of which most of them provide recommendations on prevention and control of EVD, Africa in particular still faces recurrent outbreaks of EVD, with the most recent being the 2018-2020 Kivu outbreak. This raises an intriguing question on whether African countries learn from the past outbreaks and effectively implement these recommendations. Besides, Aylward et al. had the most cited study and the highest citations could be because it was the first study to account for and give a general insight into the 2014-2016 EVD epidemic in West Africa, which is the biggest EVD outbreak in history [10]. So most of the studies that proceeded cited Aylward's study as one of their references.

The study revealed that most of the top productive journals were virology/ infectious disease-specific journals which implies that the 100 top-cited EVD studies were mostly published in subject-specific journals rather than just high impact factor journals. However, it was noted that no single African journal published any of the top-cited EVD studies. Given the fact that citation score is the most used index for recognition of published studies, this reveals that despite EVD being endemic to Africa, most, if not all, of the top quality studies are published in foreign journals. Moreover, the accessibility to these journals by African scientists and community, in general, is questionable. This could suggest that the control and prevention recommendations made from these studies just remain on paper/online if not fully accessed by African communities.

The 100 most-cited studies were produced in collaborations among different authors, countries and institutions. The analysis revealed that most of the productive authors are Western or foreign scientists, mainly from the USA and Germany. This questions the active role of African scientists in the top recognised studies, especially in the field of infectious diseases, which is the most significant public health challenge of Africa. Moreover, the USA was the most productive country contributing to 63 studies, followed by Germany and Gabon. The dominancy of USA is also highlighted in other research fields [29]. Although several African countries including Guinea, South Africa and Gabon had a significant contribution, it was mainly in collaboration with other countries, with only two single-country studies from Africa. In one perspective, this would imply the role of collaborative efforts and partnerships in achieving research advancements in this field. However, African countries need to set up and strengthen their own research facilities to enable them to carry out independent and recognisable research.

In addition, these studies were mainly produced by US and European institutions, with only one African institution singly contributing to five studies. Although the role of international agencies like WHO and governments of the EVD affected countries, including their ministries of health cannot be underestimated, it is not exhaustively reflected in the top-cited EVD studies. Besides, the funding of these studies also mainly came from USA institutions, which included the US Department of Health Human Services and NIH-USA. Therefore, public institutions in Africa and governments, in general, should increase their involvement and funding of clinical research as well as the publication of findings. This would enable evidence-based policy and decision making, especially when it comes to managing and controlling infectious diseases.

The analysis of keywords showed that the studies covered various key aspects of EVD research, including laboratory studies of the virus, its origin, transmission, as well as infections and outbreaks. Hemorrhagic fever is also highlighted as the keyword with most co-occurrence among the EVD studies. This is due to the characteristic hemorrhagic manifestation of EVD $[2,6]$, and so the term appears in most of the top-cited studies. However, studies examining the effect of EVD in particular groups of people like pregnant mothers and children were not reflected in keyword analysis nor in the research fields. This field should be thoroughly researched on to enable formulation of targeted interventions in future outbreaks.

Like other previous bibliometric analyses, our study also has some limitations $[16,17]$. First, citation analysis was based on one database, the Web of Science; thus, some essential papers indexed by other databases might have been missed $[16,22]$. The citation numbers therefor might be misleading [30], owing to self-citations, time of publications, among other factors. Thus, further studies are required using different databases to validate these findings. However, it should be noted that although citation analysis is a good measure of recognition, it is not the best index for evaluating quality or importance of scientific research [22]. Besides, since old studies have more citation than new ones, citation analysis tends to undervalue newly published studies, for example, the achievements in EVD vaccine development within the recent years are not captured in this analysis.

\section{CONCLUSIONS}

The study has characterised, and provided insights into the historical advancements of EVD research reflected through the 100 top-cited studies. The study has highlighted the leading roles played by various stakeholders, as well as the collaborative efforts exhibited not only among authors but also among countries and institutions in addressing EVD. Besides, the study has revealed that Africa's role in EVD research is lacking. Thus there is a need for African countries to invest more in clinical research and to strengthen local publication databases and journals. This would facilitate dissemination as well as more access to the valuable information contained in such prestigious studies. Given the infectiousness and severity of EVD, it remains a significant research area calling for a collaborative response, especially in times of outbreaks.

Author contributions: All authors have sufficiently contributed to the study, and agreed with the results and conclusions.

Funding: No funding source is reported for this study.

Declaration of interest: No conflict of interest is declared by authors.

Availability of data and materials: All the data supporting the results of this study are included in the article and the supplementary file. The 
raw data can also be directly obtained from the Web of Science Core Collection using the appropriate search query.

\section{REFERENCES}

1. World Health Organisation. Ebola Virus Disease [Webpage]. WHO; 2019. Available at: https://www.who.int/healthtopics/ebola/\#tab=tab_1 (Accessed: 28 December 2019).

2. Malvy D, McElroy AK, de Clerck H, Günther S, van Griensven J. Ebola virus disease. The Lancet 2019;393(10174):936948. https://doi.org/10.1016/s0140-6736(18)33132-5

3. Aurelie KK, Guy MM, Bona NF, Charles KM, Mawupemor AP, Shixue L. A Historical Review of Ebola Outbreaks. In Advances in Ebola Control. 2017. IntechOpen. https://doi.org/10.5772/intechopen.72660 PMid:30413503 PMCid:PMC6231580

4. World Health Organisation. Ebola in the Democratic Republic of the Congo-Health Emergency Update. [Webpage]. WHO; 2019. Available at: https://www.who.int/ emergencies/diseases/ebola/drc-2019 (Accessed: 29 December 2019).

5. Leroy EM, Kumulungui $B$, Pourrut $X$, Rouquet $P$, Hassanin $A$, Yaba $P$, et al. Fruit bats as reservoirs of Ebola virus. Nature. 2005;438:575-6. https://doi.org/10.1038/438575a PMid: 16319873

6. Muyembe-Tamfum JJ, Mulangu S, Masumu J, Kayembe JM, Kemp A, Paweska JT. Ebola virus outbreaks in Africa: past and present. Onderstepoort J Vet Res. 2012;79(2):a451. https://doi.org/10.4102/ojvr.v79i2.451 PMid:23327370

7. World Health Organisation. WHO prequalifies Ebola vaccine, paving the way for its use in high-risk countries. [Webpage]. WHO; 2019. Available at: https://www.who.int/news-room/detail/12-11-2019-whoprequalifies-ebola-vaccine-paving-the-way-for-its-use-inhigh-risk-countries (Accessed: 17 December 2019).

8. Henao-Restrepo AM, Longini IM, Egger $M$, Dean $N E$, Edmunds WJ, Camacho A, et al. Efficacy and effectiveness of an rVSV-vectored vaccine expressing Ebola surface glycoprotein: interim results from the Guinea ring vaccination cluster-randomised trial. The Lancet. 2015;386(9996):857-66. https://doi.org/10.1016/s01406736(15)61117-5

9. Quick J, Loman NJ, Duraffour S, Simpson JT, Severi E, Cowley L, et al. Real-time, portable genome sequencing for Ebola surveillance. Nature. 2016;530(7589):228-232. https://doi.org/10.1038/nature16996 PMid:26840485 PMCid:PMC4817224

10. Aylward B, Barboza P, Bawo L, Bertherat E, Bilivogui P, Blake I, et al. Ebola virus disease in West Africa--the first 9 months of the epidemic and forward projections. New Engl J Med. 2014;371(16):1481-95. https://doi.org/10.1056/ nejmoa1411100 PMid:25244186 PMCid:PMC4235004

11. Feldmann H, Geisbert TW. Ebola haemorrhagic fever. The Lancet 2011;377(9768):849-62. https://doi.org/10.1016/ s0140-6736(10)60667-8

12. Kawuki J, Yu X, Musa TH. Bibliometric Analysis of Ebola Research Indexed in Web of Science and Scopus (20102020). Biomed Res Int. 2020: Article ID 5476567. https://doi.org/10.1155/2020/5476567 PMid:32964036 PMCid:PMC7486633
13. Kolkailah AA, Fugar S, Vondee N, Hirji SA, Okoh AK, Ayoub A, et al. Bibliometric analysis of the top 100 most cited articles in the first 50 years of heart transplantation. Am J Cardiol. 2019;123(1):175-86. https://doi.org/10.1016/ j.amjcard.2018.09.010 PMid:30385032

14. Du L, Luo S, Liu G, Wang H, Zheng L, Zhang Y. The 100 TopCited Studies About Pain and Depression. Front Psychol. 2019;10:3072. https://doi.org/10.3389/fpsyg.2019.03072 PMid:32116876 PMCid:PMC7026489

15. Yuan F, Cai J, Liu B, Tang X. Bibliometric Analysis of 100 Top-Cited Articles in Gastric Disease. Biomed Res Int. 2020: Article ID 2672373. https://doi.org/10.1155/2020/2672373 PMid:32509853 PMCid:PMC7245662

16. Berlinberg A, Bilal J, Riaz IB, Kurtzman DJB. The 100 topcited publications in psoriatic arthritis: a bibliometric analysis. Int J Dermatol. 2018;58(9):1023-1034. https://doi.org/10.1111/ijd.14261 PMid:30315571

17. Zhang Y, Quan L, Xiao B, Du L. The 100 top-cited studies on vaccine: a bibliometric analysis. Hum Vaccin Immunother. 2019;15(12):3024-31. https://doi.org/10.1080/21645515. 2019.1614398 PMid:31112440 PMCid:PMC6930089

18. Thomson Reuters. "2019 Journal Citation Reports," Available at: http://www.isiknowledge.com (Accessed: 2 October 2020).

19. Garfield E, Paris S, Stock WG. HistCiteTM: A software tool for informetric analysis of citation linkage. Inf - Wiss Und Prax. 2006;57(8):391.

20. Aria M, Cuccurullo C. bibliometrix: An R-tool for comprehensive science mapping analysis. J Informetr. 2017;11(4):959-75.

https://doi.org/10.1016/j.joi.2017.08.007

21. Van Eck N, Waltman L. Software survey: VOSviewer, a computer program for bibliometric mapping. scientometrics. 2010;84(2):523-38. https://doi.org/10.1007 /s11192-009-0146-3 PMid:20585380 PMCid:PMC2883932

22. Zhang Y, Quan L, Du L. The 100 top-cited studies in cancer immunotherapy. Artif Cells Nanomed Biotechnol. 2019;47(1):2282-92. https://doi.org/10.1080/21691401. 2019.1623234 PMid:31169039

23. Mühlberger E, Weik M, Volchkov VE, Klenk HD, Becker S. Comparison of the transcription and replication strategies of Marburg virus and Ebola virus by using artificial replication systems. J. Virol. 1999;73(3):2333-42. https://doi.org/10.1128/jvi.73.3.2333-2342.1999 PMid:9971816 PMCid:PMC104478

24. Connolly BM, Steele KE, Davis KJ, Geisbert TW, Kell WM, Jaax NK, et al. Pathogenesis of experimental Ebola virus infection in guinea pigs. J. Infect. Dis. 1999;179(Supplement_1):S203-17. https://doi.org/10.1086/514305 PMid:9988186

25. Mupapa K, Massamba M, Kibadi K, Kuvula K, Bwaka A, Kipasa M, et al. Treatment of Ebola hemorrhagic fever with blood transfusions from convalescent patients. J. Infect. Dis. 1999;179(Supplement_1):S18-23. https://doi.org/ 10.1086/514298 PMid:9988160

26. Rowe AK, Bertolli J, Khan AS, Mukunu R, Muyembe-Tamfum JJ, Bressler D, et al. Clinical, virologic, and immunologic follow-up of convalescent Ebola hemorrhagic fever patients and their household contacts, Kikwit, Democratic Republic of the Congo. J. Infect. Dis. 1999;179(Supplement_1):S28-35. https://doi.org/10.1086/514318 PMid:9988162 
27. Khan AS, Tshioko FK, Heymann DL, Le Guenno B, Nabeth $P$, Kerstiëns $B$, et al. The reemergence of Ebola hemorrhagic fever, Democratic Republic of the Congo, 1995. J. Infect. Dis. 1999;179(Supplement_1):S76-86. https://doi.org/ 10.1086/514306 PMid:9988168

28. Rodriguez LL, De Roo A, Guimard Y, Trappier SG, Sanchez A, Bressler D, et al. Persistence and genetic stability of Ebola virus during the outbreak in Kikwit, Democratic Republic of the Congo, $1995 . \quad J$ Infect. Dis. 1999;179(Supplement_1):S170-6.

https://doi.org/10.1086/514291 PMid:9988181
29. Tao T, Zhao X, Lou J, Bo L, Wang F, Li J, Deng X. The top cited clinical research articles on sepsis: a bibliometric analysis. Critical Care. 2012 Jun;16(3):R110. https://doi.org/10.1186/ cc11401 PMid:22731930 PMCid: PMC3580668

30. Lu C, Bing Z, Bi Z, Liu M, Lu T, Xun Y, et al. Top-100 Most Cited Publications Concerning Network Pharmacology: A Bibliometric Analysis. Evid.-Based Complementary Altern. Med. 2019: Article ID 1704816. https://doi.org/10.1155/ 2019/1704816 PMid:31467569 PMCid:PMC6701366 


\section{APPENDIX 1}

The 100 Top-cited Studies in EVD Research

\begin{tabular}{|c|c|c|c|c|c|}
\hline Rank & Title and Journal & $\begin{array}{l}\text { First } \\
\text { Author }\end{array}$ & $\begin{array}{l}\text { Publication } \\
\text { year }\end{array}$ & $\begin{array}{l}\text { Number of } \\
\text { Authors }\end{array}$ & $\begin{array}{l}\text { Total } \\
\text { Citations }\end{array}$ \\
\hline 1 & $\begin{array}{c}\text { Ebola Virus Disease in West Africa - The First } 9 \text { Months of the Epidemic and Forward } \\
\text { Projections } \\
\text { N ENGL J MED }\end{array}$ & Aylward B & 2014 & 61 & 808 \\
\hline 2 & $\begin{array}{l}\text { Emergence of Zaire Ebola Virus Disease in Guinea } \\
\text { N ENGL J MED }\end{array}$ & Baize S & 2014 & 31 & 728 \\
\hline 3 & $\begin{array}{c}\text { Ebola haemorrhagic fever } \\
\text { LANCET } \\
\end{array}$ & Feldmann $\mathrm{H}$ & 2011 & 2 & 672 \\
\hline 4 & $\begin{array}{c}\text { Genomic surveillance elucidates Ebola virus origin and transmission during the } 2014 \\
\text { outbreak } \\
\text { SCIENCE }\end{array}$ & Gire SK & 2014 & 58 & 610 \\
\hline 5 & $\begin{array}{c}\text { Ebola virus entry requires the cholesterol transporter Niemann-Pick C1 } \\
\text { NATURE }\end{array}$ & Carette JE & 2011 & 15 & 600 \\
\hline 6 & $\begin{array}{l}\text { HIV-I and Ebola virus encode small peptide motifs that recruit Tsg101 to sites of particle } \\
\text { assembly to facilitate egress } \\
\text { NATURE MEDICINE }\end{array}$ & $\begin{array}{l}\text { Martin- } \\
\text { Serrano J }\end{array}$ & 2001 & 3 & 533 \\
\hline 7 & $\begin{array}{l}\text { Reversion of advanced Ebola virus disease in nonhuman primates with ZMapp } \\
\text { NATURE }\end{array}$ & Qiu XG & 2014 & 26 & 533 \\
\hline 8 & $\begin{array}{l}\text { Endosomal proteolysis of the Ebola virus glycoprotein is necessary for infection } \\
\text { SCIENCE }\end{array}$ & Chandran K & 2005 & 5 & 515 \\
\hline 9 & $\begin{array}{l}\text { Development of a preventive vaccine for Ebola virus infection in primates } \\
\text { NATURE }\end{array}$ & Sullivan NJ & 2000 & 5 & 488 \\
\hline 10 & $\begin{array}{l}\text { Ebola Hemorrhagic-Fever in Zaire, } 1976 \text { - Report of an International-Commission } \\
\text { BULL. WORLD HEALTH ORGAN }\end{array}$ & Burke J & 1978 & 47 & 443 \\
\hline 11 & $\begin{array}{l}\text { Efficacy and effectiveness of an rVSV-vectored vaccine expressing Ebola surface } \\
\text { glycoprotein: interim results from the Guinea ring vaccination cluster-randomised trial } \\
\text { LANCET }\end{array}$ & $\begin{array}{l}\text { Henao- } \\
\text { Restrepo } \\
\text { AM }\end{array}$ & 2015 & 28 & 418 \\
\hline 12 & $\begin{array}{l}\text { C-type lectins DC-SIGN and L-SIGN mediate cellular entry by Ebola virus in cis and trans } \\
\text { J. VIROL. }\end{array}$ & Alvarez CP & 2002 & 6 & 417 \\
\hline 13 & $\begin{array}{l}\text { Structure of the Ebola virus glycoprotein bound to an antibody from a human survivor } \\
\text { NATURE. }\end{array}$ & Lee JE & 2008 & 6 & 410 \\
\hline 14 & $\begin{array}{l}\text { The virion glycoproteins of Ebola viruses are encoded in two reading frames and are } \\
\text { expressed through transcriptional editing } \\
\text { P NATL ACAD SCI USA }\end{array}$ & Sanchez A & 1996 & 5 & 396 \\
\hline 15 & $\begin{array}{l}\text { Rapid detection and quantification of RNA of Ebola and Marburg viruses, Lassa virus, } \\
\text { Crimean-Congo hemorrhagic fever virus, Rift Valley fever virus, Dengue virus, and Yellow } \\
\text { fever virus by real-time reverse transcription-PCR } \\
\text { J CLIN MICROBIOL }\end{array}$ & Drosten C & 2002 & 7 & 388 \\
\hline 16 & $\begin{array}{l}\text { Live attenuated recombinant vaccine protects nonhuman primates against Ebola and } \\
\text { Marburg viruses } \\
\text { NATURE MEDICINE }\end{array}$ & Jones SM & 2005 & 14 & 388 \\
\hline 17 & $\begin{array}{l}\text { A system for functional analysis of Ebola virus glycoprotein } \\
\text { P NATL ACAD SCI USA }\end{array}$ & Takada A & 1997 & 7 & 384 \\
\hline 18 & $\begin{array}{c}\text { Real-time, portable genome sequencing for Ebola surveillance } \\
\text { NATURE }\end{array}$ & Quick J & 2016 & 102 & 381 \\
\hline 19 & $\begin{array}{l}\text { Defective humoral responses and extensive intravascular apoptosis are associated with } \\
\text { fatal outcome in Ebola virus-infected patients } \\
\text { NATURE MEDICINE }\end{array}$ & Baize S & 1999 & 10 & 374 \\
\hline 20 & $\begin{array}{l}\text { Multiple Ebola virus transmission events and rapid decline of central African wildlife } \\
\text { SCIENCE }\end{array}$ & Leroy EM & 2004 & 12 & 374 \\
\hline 21 & $\begin{array}{l}\text { Pathogenesis of Ebola hemorrhagic fever in cynomolgus macaques - Evidence that } \\
\text { dendritic cells are early and sustained targets of infection } \\
\text { AM. J. PATHOL }\end{array}$ & Geisbert TW & 2003 & 10 & 373 \\
\hline 22 & $\begin{array}{l}\text { Small molecule inhibitors reveal Niemann-Pick C1 is essential for Ebola virus infection } \\
\text { NATURE }\end{array}$ & Cote M & 2011 & 11 & 362 \\
\hline 23 & $\begin{array}{l}\text { Accelerated vaccination for Ebola virus haemorrhagic fever in non-human primates } \\
\text { NATURE }\end{array}$ & Sullivan NJ & 2003 & 9 & 343 \\
\hline 24 & $\begin{array}{l}\text { The Ebola virus VP35 protein functions as a type IIFN antagonist } \\
\text { P NATL ACAD SCI USA }\end{array}$ & Basler CF & 2000 & 8 & 338 \\
\hline 25 & $\begin{array}{l}\text { Lipid raft microdomains: A gateway for compartmentalized trafficking of Ebola and } \\
\text { Marburg viruses } \\
\text { J. EXP. MED. }\end{array}$ & Bavari S & 2002 & 10 & 329 \\
\hline 26 & $\begin{array}{l}\text { Crystal structure of the Ebola virus membrane fusion subunit, GP2, from the envelope } \\
\text { glycoprotein ectodomain } \\
\text { MOLECULAR CELL }\end{array}$ & $\begin{array}{l}\text { Weissenhor } \\
\text { n W }\end{array}$ & 1998 & 5 & 327 \\
\hline
\end{tabular}




\begin{tabular}{|c|c|c|c|c|c|}
\hline Rank & Title and Journal & $\begin{array}{l}\text { First } \\
\text { Author }\end{array}$ & $\begin{array}{l}\text { Publication } \\
\text { year }\end{array}$ & $\begin{array}{c}\text { Number of } \\
\text { Authors }\end{array}$ & $\begin{array}{l}\text { Total } \\
\text { Citations }\end{array}$ \\
\hline 27 & $\begin{array}{l}\text { Processing of the Ebola virus glycoprotein by the proprotein convertase furin } \\
\text { P NATL ACAD SCI USA }\end{array}$ & Volchkov VE & 1998 & 4 & 324 \\
\hline 28 & $\begin{array}{l}\text { Rapid diagnosis of Ebola hemorrhagic fever by reverse transcription-PCR in an outbreak } \\
\text { setting and assessment of patient viral load as a predictor of outcome } \\
\text { J. VIROL. }\end{array}$ & Towner JS & 2004 & 13 & 323 \\
\hline 29 & $\begin{array}{l}\text { Epitopes involved in antibody-mediated protection from Ebola virus } \\
\text { SCIENCE }\end{array}$ & Wilson JA & 2000 & 7 & 321 \\
\hline 30 & $\begin{array}{l}\text { A PPXY motif within the VP40 protein of Ebola virus interacts physically and functionally } \\
\text { with a ubiquitin ligase: Implications for filovirus budding } \\
\text { P NATL ACAD SCI USA }\end{array}$ & Harty RN, & 2000 & 5 & 319 \\
\hline 31 & $\begin{array}{l}\text { The Ebola virus VP35 protein inhibits activation of interferon regulatory factor } 3 \\
\text { J. VIROL. }\end{array}$ & Basler CF & 2003 & 9 & 319 \\
\hline 32 & $\begin{array}{c}\text { Clinical Illness and Outcomes in Patients with Ebola in Sierra Leone } \\
\text { N ENGL J MED }\end{array}$ & $\begin{array}{l}\text { Schieffelin } \\
\text { JS }\end{array}$ & 2014 & 47 & 318 \\
\hline 33 & $\begin{array}{l}\text { Newly Discovered Ebola Virus Associated with Hemorrhagic Fever Outbreak in Uganda } \\
\text { PLOS PATHOGENS }\end{array}$ & Towner JS, & 2008 & 18 & 314 \\
\hline 34 & $\begin{array}{l}\text { Postexposure protection of non-human primates against a lethal Ebola virus challenge } \\
\text { with RNA interference: a proof-of-concept study } \\
\text { LANCET }\end{array}$ & Geisbert TW & 2010 & 12 & 310 \\
\hline 35 & $\begin{array}{l}\text { Comparison of the transcription and replication strategies of Marburg virus and Ebola } \\
\text { virus by using } \\
\text { artificial replication systems } \\
\text { J. VIROL. }\end{array}$ & $\begin{array}{l}\text { Muhlberger } \\
\qquad \mathrm{E}\end{array}$ & 1999 & 5 & 296 \\
\hline 36 & $\begin{array}{l}\text { Identification of the Ebola virus glycoprotein as the main viral determinant of vascular } \\
\text { cell cytotoxicity and injury } \\
\text { NATURE MEDICINE }\end{array}$ & Yang ZY & 2000 & 6 & 285 \\
\hline 37 & $\begin{array}{l}\text { Role of endosomal cathepsins in entry mediated by the Ebola virus glycoprotein } \\
\text { J. VIROL. }\end{array}$ & $\begin{array}{l}\text { Schornberg } \\
\mathrm{K}\end{array}$ & 2006 & 6 & 282 \\
\hline 38 & $\begin{array}{l}\text { Ebola virus VP35 protein binds double-stranded RNA and inhibits alpha/beta interferon } \\
\text { production induced by RIG-I signaling } \\
\text { J. VIROL. }\end{array}$ & $\begin{array}{l}\text { Cardenas } \\
\text { WB }\end{array}$ & 2006 & 8 & 281 \\
\hline 39 & $\begin{array}{l}\text { Ebola virus VP24 binds karyopherin alpha } 1 \text { and blocks STAT1 nuclear accumulation } \\
\text { J. VIROL. }\end{array}$ & Reid SP & 2006 & 9 & 277 \\
\hline 40 & $\begin{array}{c}\text { Ebola Hemorrhagic-Fever In Sudan, } 1976 \text { - Report of a WHO International Study Team } \\
\text { BULL. WORLD HEALTH ORGAN }\end{array}$ & Deng IM & 1978 & 26 & 273 \\
\hline 41 & $\begin{array}{c}\text { GP mRNA of Ebola virus is edited by the Ebola virus polymerase and by T7 and vaccinia } \\
\text { virus polymerases } \\
\text { VIROLOGY }\end{array}$ & Volchkov VE & 1995 & 7 & 268 \\
\hline 42 & $\begin{array}{l}\text { Preliminary-Report - Isolation of Ebola Virus from monkeys imported to USA } \\
\text { LANCET }\end{array}$ & Jahrling Pb & 1990 & 7 & 265 \\
\hline 43 & $\begin{array}{l}\text { Characterization of Ebola virus entry by using pseudotyped viruses: Identification of } \\
\text { receptor-deficient cell lines } \\
\text { J.VIROL. }\end{array}$ & $\begin{array}{l}\text { Wool-Lewis } \\
\qquad \text { Rj }\end{array}$ & 1998 & 2 & 264 \\
\hline 44 & $\begin{array}{l}\text { Human asymptomatic Ebola infection and strong inflammatory response } \\
\text { LANCET }\end{array}$ & Leroy EM & 2000 & 10 & 264 \\
\hline 45 & $\begin{array}{c}\text { Ebola hemorrhagic fever in Kikwit, Democratic Republic of the Congo: Clinical } \\
\text { observations in } 103 \text { patients } \\
\text { J. INFECT. DIS }\end{array}$ & Bwaka MA & 1999 & 18 & 257 \\
\hline 46 & $\begin{array}{l}\text { Efficacy and effectiveness of an rVSV-vectored vaccine in preventing Ebola virus disease: } \\
\text { final results from the Guinea ring vaccination, open-label, cluster-randomised trial } \\
\text { (Ebola Ca Suffit!) } \\
\text { LANCET }\end{array}$ & $\begin{array}{l}\text { Henao- } \\
\text { Restrepo } \\
\quad \text { Am }\end{array}$ & 2017 & 32 & 253 \\
\hline 47 & $\begin{array}{l}\text { Tetherin-mediated restriction of filovirus budding is antagonized by the Ebola } \\
\text { glycoprotein } \\
\text { P NATL ACAD SCI USA }\end{array}$ & Kaletsky RL & 2009 & 4 & 252 \\
\hline 48 & $\begin{array}{c}\text { Human Ebola Outbreak Resulting from Direct Exposure to Fruit Bats in Luebo, } \\
\text { Democratic Republic of Congo, } 2007 \\
\text { VECTOR BORNE ZOONOT. }\end{array}$ & Leroy EM & 2009 & 7 & 252 \\
\hline 49 & $\begin{array}{l}\text { The reemergence of Ebola hemorrhagic fever, Democratic Republic of the Congo, } 1995 \\
\text { J. INFECT. DIS }\end{array}$ & Khan AS & 1999 & 19 & 251 \\
\hline 50 & $\begin{array}{l}\text { Treatment of Ebola virus infection with a recombinant inhibitor of factor Vila/tissue } \\
\text { factor: a study in rhesus monkeys } \\
\text { LANCET }\end{array}$ & Geisbert TW & 2003 & 10 & 249 \\
\hline 51 & $\begin{array}{l}\text { Impairment of dendritic cells and adaptive immunity by Ebola and lassa viruses } \\
\text { J IMMUNOL. }\end{array}$ & Mahanty S & 2003 & 6 & 247 \\
\hline 52 & $\begin{array}{l}\text { Treatment of Ebola hemorrhagic fever with blood transfusions from convalescent } \\
\text { patients } \\
\text { J. INFECT. DIS }\end{array}$ & Mupapa K & 1999 & 8 & 242 \\
\hline
\end{tabular}




\begin{tabular}{|c|c|c|c|c|c|}
\hline Rank & Title and Journal & $\begin{array}{l}\text { First } \\
\text { Author }\end{array}$ & $\begin{array}{l}\text { Publication } \\
\text { year }\end{array}$ & $\begin{array}{c}\text { Number of } \\
\text { Authors }\end{array}$ & $\begin{array}{c}\text { Total } \\
\text { Citations }\end{array}$ \\
\hline 53 & $\begin{array}{l}\text { Sequence-Analysis of The Ebola Virus Genome - Organization, Genetic Elements, And } \\
\text { Comparison with The Genome of Marburg Virus } \\
\text { VIRUS RESEARCH }\end{array}$ & Sanchez A & 1993 & 4 & 238 \\
\hline 54 & $\begin{array}{c}\text { Cellular Entry of Ebola Virus Involves Uptake by a Macropinocytosis-Like Mechanism and } \\
\text { Subsequent Trafficking through Early and Late Endosomes } \\
\text { PLOS PATHOGENS }\end{array}$ & Saeed MF & 2010 & 4 & 238 \\
\hline 55 & $\begin{array}{l}\text { DC-SIGN and DC-SIGNR bind Ebola glycoproteins and enhance infection of macrophages } \\
\text { and endothelial cells } \\
\text { VIROLOGY }\end{array}$ & Simmons G & 2003 & 13 & 237 \\
\hline 56 & $\begin{array}{l}\text { Clinical virology of Ebola hemorrhagic fever (EHF): Virus, virus antigen, and IgG and IgM } \\
\text { antibody findings among EHF patients in Kikwit, Democratic Republic of the Congo, } 1995 \\
\text { J. INFECT. DIS }\end{array}$ & Ksiazek TG & 1999 & 13 & 236 \\
\hline 57 & $\begin{array}{l}\text { Isolation And Partial Characterization of a New Strain of Ebola Virus } \\
\text { LANCET }\end{array}$ & Leguenno B & 1995 & 6 & 235 \\
\hline 58 & $\begin{array}{c}\text { Clinical Presentation of Patients with Ebola Virus Disease in Conakry, Guinea } \\
\text { N ENGL J MED }\end{array}$ & Bah El & 2015 & 28 & 235 \\
\hline 59 & $\begin{array}{l}\text { Ebola virus VP40 drives the formation of virus-like filamentous particles along with GP } \\
\text { J. VIROL. }\end{array}$ & Noda T & 2002 & 6 & 227 \\
\hline 60 & $\begin{array}{l}\text { The Ebola virus VP35 protein is a suppressor of RNA silencing } \\
\text { PLOS PATHOGENS }\end{array}$ & Haasnoot J & 2007 & 6 & 226 \\
\hline 61 & $\begin{array}{l}\text { Clinical, virologic, and immunologic follow-up of convalescent Ebola hemorrhagic fever } \\
\text { patients and their household contacts, Kikwit, Democratic Republic of the Congo } \\
\text { J. INFECT. DIS }\end{array}$ & Rowe AK & 1999 & 13 & 223 \\
\hline 62 & $\begin{array}{c}\text { Case of Ebola Virus-Infection } \\
\text { BRIT MED J }\end{array}$ & Emond Rtd & 1977 & 4 & 220 \\
\hline 63 & $\begin{array}{l}\text { Ebola Virus-Disease in Southern Sudan - Hospital Dissemination and Intrafamilial Spread } \\
\text { BULL. WORLD HEALTH ORGAN }\end{array}$ & Baron Rc & 1983 & 3 & 219 \\
\hline 64 & $\begin{array}{l}\text { Delayed treatment of Ebola virus infection with plant-derived monoclonal antibodies } \\
\text { provides protection in rhesus macaques } \\
\text { P NATL ACAD SCI USA }\end{array}$ & Olinger GG & 2012 & 17 & 218 \\
\hline 65 & $\begin{array}{l}\text { Pathogenesis of Ebola hemorrhagic fever in primate models - Evidence that hemorrhage } \\
\text { is not a direct effect of virus-induced cytolysis of endothelial cells } \\
\text { AM. J. PATHOL }\end{array}$ & Geisbert TW & 2003 & 7 & 217 \\
\hline 66 & $\begin{array}{l}\text { Inflammatory responses in Ebola virus-infected patients } \\
\text { CLIN. EXP. IMMUNOL. }\end{array}$ & Baize S & 2002 & 8 & 216 \\
\hline 67 & $\begin{array}{l}\text { The basic reproductive number of Ebola and the effects of public health measures: the } \\
\text { cases of Congo and Uganda } \\
\text { J. THEOR. BIOL }\end{array}$ & Chowell G & 2004 & 5 & 216 \\
\hline 68 & $\begin{array}{l}\text { Persistence of Ebola Virus in Ocular Fluid during Convalescence } \\
\text { N ENGL J MED }\end{array}$ & Varkey JB & 2015 & 14 & 216 \\
\hline 69 & $\begin{array}{l}\text { Lethal Experimental Infections Of Rhesus-Monkeys by Aerosolized Ebola-Virus } \\
\text { INT J EXP PATHOL }\end{array}$ & Johnson E & 1995 & 4 & 212 \\
\hline 70 & $\begin{array}{l}\text { Clinical Care of Two Patients with Ebola Virus Disease in the United States } \\
\text { N ENGL J MED }\end{array}$ & Lyon GM & 2014 & 12 & 212 \\
\hline 71 & $\begin{array}{c}\text { Experimental inoculation of plants and animals with Ebola virus } \\
\text { EMERG INFECT DIS }\end{array}$ & $\begin{array}{l}\text { Swanepoel } \\
\mathrm{R}\end{array}$ & 1996 & 9 & 211 \\
\hline 72 & $\begin{array}{l}\text { Apoptosis induced in vitro and in vivo during infection by Ebola and Marburg viruses } \\
\text { LAB. INVESTIG }\end{array}$ & Geisbert TW & 2000 & 6 & 207 \\
\hline 73 & $\begin{array}{l}\text { Markedly elevated levels of interferon (IFN)-gamma, IFN-alpha, interleukin (IL)-2, IL-10, } \\
\text { and tumor necrosis factor-alpha associated with fatal Ebola virus infection } \\
\text { J. INFECT. DIS }\end{array}$ & Villinger F & 1999 & 10 & 206 \\
\hline 74 & $\begin{array}{l}\text { Distinct cellular interactions of secreted and transmembrane Ebola virus glycoproteins } \\
\text { SCIENCE }\end{array}$ & Yang ZY & 1998 & 7 & 205 \\
\hline 75 & $\begin{array}{c}\text { Pathogenesis of experimental Ebola virus infection in guinea pigs } \\
\text { J. INFECT. DIS }\end{array}$ & $\begin{array}{l}\text { Connolly } \\
\text { BM }\end{array}$ & 1999 & 7 & 205 \\
\hline 76 & $\begin{array}{c}\text { Core structure of the envelope glycoprotein GP2 from Ebola virus at 1.9-angstrom } \\
\text { resolution } \\
\text { P NATL ACAD SCI USA }\end{array}$ & $\begin{array}{l}\text { Malashkevic } \\
\text { h VN }\end{array}$ & 1999 & 6 & 205 \\
\hline 77 & $\begin{array}{l}\text { Recovery of infectious Ebola virus from complementary DNA: RNA editing of the GP gene } \\
\text { and viral cytotoxicity } \\
\text { SCIENCE. }\end{array}$ & Volchkov VE & 2001 & 7 & 205 \\
\hline 78 & $\begin{array}{l}\text { Persistence and genetic stability of Ebola virus during the outbreak in Kikwit, } \\
\text { Democratic Republic of the Congo, } 1995 \\
\text { J. INFECT. DIS }\end{array}$ & $\begin{array}{c}\text { Rodriguez } \\
\text { LL }\end{array}$ & 1999 & 13 & 203 \\
\hline 79 & $\begin{array}{c}\text { Successful treatment of advanced Ebola virus infection with T-705 (favipiravir) in a small } \\
\text { animal model } \\
\text { ANTIVIRAL RESEARCH }\end{array}$ & $\begin{array}{l}\text { Oestereich } \\
\mathrm{L}\end{array}$ & 2014 & 6 & 203 \\
\hline
\end{tabular}




\begin{tabular}{|c|c|c|c|c|c|}
\hline Rank & Title and Journal & $\begin{array}{l}\text { First } \\
\text { Author }\end{array}$ & $\begin{array}{l}\text { Publication } \\
\text { year }\end{array}$ & $\begin{array}{c}\text { Number of } \\
\text { Authors }\end{array}$ & $\begin{array}{c}\text { Total } \\
\text { Citations } \\
\end{array}$ \\
\hline 80 & $\begin{array}{l}\text { Human Fatal Zaire Ebola Virus Infection Is Associated with an Aberrant Innate Immunity } \\
\text { and with Massive Lymphocyte Apoptosis } \\
\text { PLOS NEGL. TROP. DIS }\end{array}$ & Wauquier $\mathrm{N}$ & 2010 & 5 & 200 \\
\hline 81 & $\begin{array}{c}\text { Ebola outbreak killed } 5000 \text { gorillas } \\
\text { SCIENCE }\end{array}$ & Bermejo M & 2006 & 6 & 199 \\
\hline 82 & $\begin{array}{l}\text { An interferon-alpha-induced tethering mechanism inhibits HIV-1 and ebola virus particle } \\
\text { release but is counteracted by the HIV-1 Vpu protein } \\
\text { CELL HOST \& MICROBE }\end{array}$ & Neil SJD & 2007 & 4 & 199 \\
\hline 83 & $\begin{array}{c}\text { Molecular Evidence of Sexual Transmission of Ebola Virus } \\
\text { N ENGL J MED }\end{array}$ & Mate SE & 2015 & 41 & 199 \\
\hline 84 & $\begin{array}{l}\text { Ebola virus can be effectively neutralized by antibody produced in natural human } \\
\text { infection } \\
\text { J. VIROL. }\end{array}$ & Maruyama T & 1999 & 9 & 196 \\
\hline 85 & $\begin{array}{l}\text { Successful Treatment of Ebola Virus-Infected Cynomolgus Macaques with Monoclonal } \\
\text { Antibodies } \\
\text { SCI. TRANSL. MED }\end{array}$ & Qiu XG & 2012 & 11 & 196 \\
\hline 86 & $\begin{array}{l}\text { Overlapping motifs (PTAP and PPEY) within the Ebola virus VP40 protein function } \\
\text { independently as late budding domains: Involvement of host proteins TSG101 and VPS-4 } \\
\text { J. VIROL. }\end{array}$ & Licata JM & 2003 & 6 & 191 \\
\hline 87 & $\begin{array}{l}\text { Will Ebola change the game? Ten essential reforms before the next pandemic. The report } \\
\text { of the Harvard-LSHTM Independent Panel on the Global Response to Ebola } \\
\text { LANCET }\end{array}$ & Moon S & 2015 & 22 & 191 \\
\hline 88 & $\begin{array}{l}\text { A Case of Severe Ebola Virus Infection Complicated by Gram-Negative Septicemia } \\
\text { N ENGL J MED }\end{array}$ & Kreuels B & 2014 & 12 & 190 \\
\hline 89 & $\begin{array}{l}\text { Ebola virus VP40-induced particle formation and association with the lipid bilayer } \\
\text { J. VIROL. }\end{array}$ & $\begin{array}{l}\text { Jasenosky } \\
\text { LD }\end{array}$ & 2001 & 4 & 188 \\
\hline 90 & $\begin{array}{c}\text { Phase } 1 \text { Trials of rVSV Ebola Vaccine in Africa and Europe } \\
\text { N ENGL J MED }\end{array}$ & Agnandji ST & 2016 & 58 & 188 \\
\hline 91 & $\begin{array}{l}\text { Effective post-exposure treatment of Ebola infection } \\
\text { PLOS PATHOGENS }\end{array}$ & Feldmann $\mathrm{H}$ & 2007 & 12 & 187 \\
\hline 92 & $\begin{array}{l}\text { Analysis of human peripheral blood samples from fatal and nonfatal cases of Ebola } \\
\text { (Sudan) hemorrhagic fever: Cellular responses, virus load, and nitric oxide levels } \\
\text { J. VIROL. }\end{array}$ & Sanchez A & 2004 & 7 & 180 \\
\hline 93 & $\begin{array}{l}\text { Differential N-linked glycosylation of human immunodeficiency virus and Ebola virus } \\
\text { envelope glycoproteins modulates interactions with DC-SIGN and DC-SIGNR } \\
\text { J. VIROL. }\end{array}$ & $\operatorname{Lin} G$ & 2003 & 11 & 179 \\
\hline 94 & $\begin{array}{l}\text { Evaluation of immune globulin and recombinant interferon-alpha } 2 \mathrm{~b} \text { for treatment of } \\
\text { experimental Ebola virus infections } \\
\text { J. INFECT. DIS }\end{array}$ & Jahrling PB & 1999 & 9 & 178 \\
\hline 95 & $\begin{array}{c}\text { Immunization for Ebola virus infection } \\
\text { NATURE MEDICINE }\end{array}$ & Xu L & 1998 & 7 & 176 \\
\hline 96 & $\begin{array}{l}\text { Lethal experimental infection of rhesus monkeys with Ebola-Zaire (Mayinga) virus by the } \\
\text { oral and conjunctival route of exposure } \\
\text { ARCH PATHOL LAB MED }\end{array}$ & Jaax NK & 1996 & 7 & 175 \\
\hline 97 & $\begin{array}{c}\text { Ebola virus entry requires the host-programmed recognition of an intracellular receptor } \\
\text { EMBO JOURNAL }\end{array}$ & Miller EH & 2012 & 16 & 173 \\
\hline 98 & $\begin{array}{l}\text { Two-pore channels control Ebola virus host cell entry and are drug targets for disease } \\
\text { treatment } \\
\text { SCIENCE }\end{array}$ & Sakurai Y & 2015 & 10 & 173 \\
\hline 99 & $\begin{array}{l}\text { Experimental Treatment with Favipiravir for Ebola Virus Disease (the JIKI Trial): A } \\
\text { Historically Controlled, Single-Arm Proof-of-Concept Trial in Guinea } \\
\text { PLOS MEDICINE }\end{array}$ & Sissoko D & 2016 & 132 & 170 \\
\hline 100 & $\begin{array}{l}\text { ISG15 inhibit Ebola VP40VLP budding in an L-domain-dependent manner by blocking } \\
\text { Nedd4 ligase activity } \\
\text { P NATL ACAD SCI USA }\end{array}$ & Okumura A & 2008 & 3 & 169 \\
\hline
\end{tabular}

